\title{
SPECYFIKA REALIZACJI LINIOWYCH INWESTYCJI W PASIE DROGOWYM W AGLOMERACJI MIEJSKIEJ Z UWZGLĘDNIENIEM OBSZARÓW ZABYTKOWYCH
}

\begin{abstract}
Treścią referatu jest problematyka budowlanego procesu inwestycyjnego w pasie drogowym na terenie miast. W aglomeracjach miejskich realizacja zadań związanych z budową, przebudową lub modernizacją ciągów drogowych lub sieci infrastruktury liniowej związana jest z pokonaniem szczególnych utrudnień. Wynika to nie tylko ze specyfiki technologicznej ale również z szeroko pojętej interakcji społecznych. Inwestorzy realizujący zadania w miastach muszą szukać nie tylko innowacyjnych rozwiązań technicznych ale również muszą spełniać, często - „wygórowane" oczekiwania społeczne. W referacie omówione zostaną typowe zagrożenia procesu inwestycyjnego na etapach koncepcji, projektowania, realizacji i eksploatacji - ze szczególnym uwzględnieniem aspektów dotyczących realizacji liniowych robót budowlanych na obszarach objętych warunkami ochrony, wynikającymi z zapisów ustawy o ochronie zabytków[1]. Należy podkreślić, że ochrona ta zgodnie $\mathrm{z}$ Art. 4 przedmiotowej Ustawy polega, na podejmowaniu przez organy administracji publicznej działań mających między innymi na celu: zapewnienie warunków prawnych, organizacyjnych i finansowych, umożliwiających trwałe zachowanie zabytków oraz ich zagospodarowanie i utrzymanie. Przekłada się to na obligatoryjny warunek prowadzenia prac konserwatorskich, restauratorskich i oczywiście robót budowlanych za pozwoleniem właściwego konserwatora zabytków i pod jego nadzorem. Realizacja liniowych zadań inwestycyjnych z natury rzeczy odbywa się nie tylko w obszarze wpływu zabytków nieruchomych ale także w bezpośrednim kontakcie z zabytkami archeologicznymi tj. - zabytkami nieruchomymi, będącymi powierzchniową, podziemną lub podwodną pozostałością egzystencji i działalności człowieka, złożoną z nawarstwień kulturowych i znajdujących się w nich wytworów bądź ich śladów. Warunkiem pogodzenia interesów stron tego skomplikowanego procesu budowlanego oraz spełnienie ustawowych wymagań formalno-prawnych jest sprawna koordynacja projektowania i realizacji oraz akceptacja społeczna zamierzenia inwestycyjnego.
\end{abstract}

Słowa kluczowe: budowa, modernizacja, infrastruktura drogowa, obszary zurbanizowane, ochrona zabytków, koordynacja inwestycji, systyem e_inwestycje

\footnotetext{
${ }^{1}$ Andrzej Marecki, Politechnika Warszawska, Wydział Inżynierii Lądowej, Al. Armii Ludowej 16, 00-637 Warszawa. amarecki@il.pw.edu.pl
} 


\section{Wprowadzenie}

W artykule 3 Ustawy Prawo Budowlane [2] wyodrębniono szczególny rodzaj obiektu budowlanego tzw. obiekt liniowy, który nie jest budynkiem lub obiektem małej architektury. Charakterystycznym parametrem dla tego typu obiektów jest długość. Zgodnie z ustawą [2] są to; droga wraz ze zjazdami, linia kolejowa, wodociąg, kanał, gazociąg, ciepłociąg, linia i trakcja elektroenergetyczna, linia kablowa nadziemna i umieszczona bezpośrednio w ziemi, podziemna, wał przeciwpowodziowy oraz kanalizacja kablowa. Do grupy obiektów, których charakterystycznym parametrem jest długość należą również wyodrębnione w ustawie mosty, wiadukty, estakady i tunele. Zadania inwestycyjne dotyczące wymienionych obiektów i budowli wymagają na ogół ingerencji w pas drogowy.

Na przykład w Warszawie w okresie od 2008 r. do maja 2016 r. wg danych zebranych w systemie e_inwestycje obsługiwanym przez Biuro Koordynacji Inwestycji i Remontów w Pasie Drogowym (BKIiRwPD), zarejestrowano 13457 planowanych zajęć pasa drogowego ${ }^{2}$. W Tab. 1 podano wykaz wnioskodawców oraz ilości zajęć pasa drogowego. Zajęcia pasa drogowego podzielono na trzy typy: liniowe dla inwestycji związanych z przebudową sieci infrastrukturalnych, pasmowe dla robót drogowych, mostowych, tunelowych i mieszane dla robót utrzymaniowych.

Tabela 1. Planowane zajęcia pasa drogowego w Warszawie od 2008 do 2016 (źródło system e_inwestycje)

Table 1. The planned accupation of roadways in Warsaw since 2008 to 2016 (source system e_inwestycje)

\begin{tabular}{|c|c|c|c|c|}
\hline Wnioskodawca $^{3}$ & $\begin{array}{c}\text { Zajęcia } \\
\text { liniowe }\end{array}$ & $\begin{array}{c}\text { Zajęcia } \\
\text { pasmowe }\end{array}$ & $\begin{array}{c}\text { Zajęcia } \\
\text { mieszane }\end{array}$ & $\begin{array}{c}\text { Zajęcia } \\
\text { razem }\end{array}$ \\
\hline GDDKiA & & 41 & & \\
\hline METRO & & 48 & & \\
\hline PKP PLK & & 91 & & \\
\hline TW & & 228 & & 1423 \\
\hline ZTM & & 899 & & \\
\hline ZMID & & 116 & & \\
\hline MPWIK & 5175 & & & 8806 \\
\hline PSG & 2022 & & & \\
\hline RWE & 546 & & & 1004 \\
\hline VEOLIA & 1063 & & & 13228 \\
\hline ZDM & & & & \\
\hline DZIELNICE & & & & \\
\hline Suma & & &
\end{tabular}

\footnotetext{
${ }^{2}$ Badania własne autora, który jest naczelnikiem Wydziału Koordynacji w BKIiRwPD m. st. Warszawy ${ }^{3}$ GDDKiA - Generalna Dyrekcja Dróg Krajowych i Autostrad, TW - Tramwaje Warszawskie, ZTM Zarząd Transportu Miejskiego, ZMID Zarząd Inwestycji Miejskich, PSG Polska Spółka Gazownictwa, RWE Warszawa (sieć elektryczna), VEOLIA (sieć energetyczne), ZDM - Zarząd Dróg Miejskich
} 
Zadania inwestycyjne realizowane $\mathrm{w}$ pasie drogowym w aglomeracji miejskiej są końcowym etapem procesu inwestycyjnego, którego przebieg podlega specyficznej kontroli na każdym etapie, począwszy od koncepcji, a skończywszy na eksploatacji. Istotna rolę odgrywają tu zarówno podmioty administracji państwowej jak i opinia społeczna. Minimalizowanie wpływu inwestycji w pasie drogowym na funkcjonowanie systemu transportowego i komunikacji miejskiej jest nadrzędnym warunkiem akceptacji warunków zajęcia pasa drogowego.

$\mathrm{W}$ procesie inwestycyjnym należy równie uwzględnić postulaty dotyczące warunków zrównoważonego rozwoju, które wynikają z warunków ochrony środowiska oraz zapisów ustawy o ochronie zabytków [1].

\section{Wybrane zagadnienia dotyczące specyfiki realizacji inwestycji liniowych w pasie drogowym w mieście}

Proces inwestycyjny składa się $\mathrm{z}$ wielu etapów; głównie przygotowania i realizacji danego zadania. Przygotowanie to zaplanowanie i zaprojektowanie inwestycji, pozyskanie praw do terenu, otrzymanie niezbędnych decyzji oraz zapewnienie środków pozwalających na sprawną jej realizację. Analiza wymienionych 13457 planowanych ingerencji w pas drogowy w celu realizacji zadania inwestycyjnego, remontu, wymiany nawierzchni, przebudowy infrastruktury liniowej, wykonania przyłączy i tym podobnych, pozwoliła na wyodrębnienie charakterystycznych, powtarzających się w tym procesie problemów. Dotyczą one opracowania koncepcji wykonanie projektu, pozyskanie prawa do terenu, otrzymania niezbędnych decyzji oraz zapewnienie środków pozwalających na sprawną jej realizację. W skrócie etapy te to: koncepcja, projekt, realizacja oraz eksploatacja.

\subsection{Koncepcja - dialog społeczny}

Prawidłowo przygotowana inwestycja powinna być poprzedzona dyskusją publiczną, która pozwoli na rzetelne przeanalizowanie projektów planowanych rozwiązań. Poprawnie przeprowadzone konsultacje znacznie przyspieszają proces uzyskiwania decyzji administracyjnych. Natomiast brak tych konsultacji lub też przeprowadzenie ich niewłaściwie skutkuję zwykle niemożnością rozpoczęcia robót i eskalacją żądań ze strony mieszkańców. Zaobserwowany wydłużający się okres projektowania ma negatywny wpływ na realizację inwestycji.

W związku ze zmianami w przestrzeni publicznej wokół planowanej inwestycji, tracą na ważności ustalenia z konsultacji społecznych lub się po prostu o nich zapomina ${ }^{4}$.

\footnotetext{
${ }^{4}$ Ulica Czerniakowska Bis. Projekt konsultowany w roku 2008. Przez sześć lat wybudowano w pobliżu zamierzenia inwestycyjnego wiele nowych osiedli, które wygenerowały nowe uwarunkowania dla przestrzeni publicznej. Trasa Świętokrzyska. Postulat społeczny dotyczący korekty przebiegu planowanej Trasy Świętokrzyskiej poprzez maksymalne dosuniecie Trasy do istniejących torów kolei legionowskiej zgłoszono już w lipcu 2009 r. Projektant nie uwzględnił tego postulatu. Efekt, w listopadzie 2013 organizacje pozarządowa zgłosiła protest przeciwko budowie trasy przez park. W lipcu 2014 inwestor posiadając ZRID wstrzymał ogłoszenie przetargu w formule ,projektuj i buduj”. Wrócono do fazy projektowej.
} 


\subsection{Koncepcja - Wieloletnia Prognoza Finansowa (WPF)}

$\mathrm{Na}$ etapie koncepcji trzeba stworzyć instrumenty gwarantujące płynne finansowanie inwestycji. Niedopuszczalne jest wielokrotne projektowanie, a w przypadku niezbędnych cięć budżetowych warunkiem sine qua non powinna być ponowna wielokryterialna ocena i analiza projektu. Zmiana zakresu rzeczowego inwestycji musi uwzględniać efekty funkcjonalne takiej zmiany. Obniżenie kosztów inwestycji przez rezygnacje z realizacji pewnych elementów - np. zmiana skrzyżowania bezkolizyjnego $\mathrm{w}$ skrzyżowanie $\mathrm{w}$ poziomie zero, może pogorszyć warunki komunikacyjne - stawiając tym samym pod znakiem zapytania racjonalność całego przedsięwzięcia ${ }^{5}$.

\subsection{Projekt - , Decyzja Środowiskowa”}

Celem decyzji środowiskowej jest ocena zagrożeń oraz ich skali na etapie planowania inwestycji, a ostatecznie przeciwdziałanie tym zagrożeniom lub ich minimalizację. $Z$ tego powodu decyzja środowiskowa wydawana jest przed decyzją pozwolenie na budowę. Tymczasem obserwowane jest zjawisko odwrócenia tego procesu. Decyzja środowiskowa nie może być uzasadnieniem dla realizacji przedsięwzięcia. Występując $\mathrm{z}$ wnioskiem o wydanie decyzji warto wystąpić jednocześnie z wnioskiem o ustalenie zakresu raportu. Organ przed sporządzeniem raportu wskaże jakie komponenty powinien on zawierać, co znacznie skróci czas postępowania, głównie jego analizy i ewentualnych uzupełnień. Skraca również czas postępowania właściwe zdefiniowanie kryteriów na podstawie, których ustalane są strony postępowania. Ustawa dotycząca decyzji środowiskowej [3] nie precyzuje kogo należy uznać za stronę, dlatego niejednokrotnie inwestor sztucznie ogranicza ilości działek na których realizowane jest zadanie. To z kolei prowadzi do tego, że inwestor skraca listę potencjalnych konfliktów społecznych.

Inwestorzy wraz z projektantami często zapominają o konieczności włączenia do zespołu osób zajmujących się konsultacjami środowiskowymi. Jeżeli inwestor już na wczesnym etapie przygotowania inwestycji rozpozna uwarunkowania środowiskowe to będzie mógł efektywnie skoordynować w rozwiązaniu projektowym postulaty środowiskowe z programem funkcjonalno-użytkowym. Również wykonawca otrzyma dokumentację wolną od błędów, która pozwoli na rzetelne opracowanie harmonogramów, a realizacja nie będzie generowała kosztów dodatkowych ${ }^{6}$.

\footnotetext{
${ }^{5}$ Ulica Lodygowa. W 2009 r. powstał projekt przebudowy oraz uzyskano decyzję środowiskową. Brak środków finansowych wstrzymał realizację. Ponownie Środki na realizacje zaplanowano w WPF na lata 2015-2016. W 2015 r. zawarto ponownie umowę z nowym projektantem na uzyskanie nowej decyzji środowiskowej, dokonanie zmian projektu na bazie nowej decyzji oraz aktualizację uzgodnień z gestorami sieci i przygotowanie dokumentacji do ZRID

${ }^{6}$ Projekty kierowane do realizacji będące integralnym elementem materiałów przetargowych i kontraktowych często zawierały niedokładne przedmiary, nie odpowiadały współczesnym standardom technicznym, opierały się na niekompletnych danych dotyczących warunków własnościowych, nie uwzględniały zmian w lokalizacji sieci: infrastruktury energetycznej, teletechnicznej, wodociągowej itp.
} 


\subsection{Projekt - kolizje}

Praktycznie przy realizacji każdej budowy występuje konieczności dokonanie przebudowy lub przełożenia podziemnej infrastruktury. Najczęściej mamy do czynienia z kolizjami związanymi z sieciami energetycznej i teletechnicznymi. Problemy z tym związane mają szczególny charakter, który wynika ze specyficznych uwarunkowań prawnych oraz technicznych. Dodatkowym aspektem w przypadku sieci energetycznych jest kwestia odpowiedzialności karnej.

Zbliżenie nowej inwestycji do istniejącej linii energetycznej może nastąpić po spełnieniu określonych wymogów technicznych. Przede wszystkim nie można dopuścić do pogorszenia warunków eksploatacyjnych istniejącego układu sieci, ponadto każde usunięcie kolizji energetycznej wiąże się z koniecznością wyłączenia zasilania. Zgodnie z tzw." Instrukcją ruchu" w przypadku sieci wysokich napięć, informacja o wyłączeniu powinna dotrzeć do operatora z rocznym wyprzedzeniem. W pozostałych przypadkach okres minimum to trzy miesiące. Dlatego usprawnienie usuwania kolizji energetycznych powinno: rozpoczynać się już na etapie wczesnego projektowania. Projektant nie powinien koncentrować się wyłącznie na przedsięwzięciu głównym ale również powinien dokonać rzetelnej inwentaryzacji całej infrastruktury, która ma być przebudowana lub przełożona. W projekcie powinien znaleźć się Przynajmniej podstawowy zakres robót - nie muszą to być ostateczne rozwiązania, ale musi to być niezbędny program minimum. Dokumentacja powinna również przewidywać możliwość wyłączeń sieci dla realizacji zasadniczych prac budowlanych. Jeżeli chodzi o prawa własnościowe to powinny one być zdefiniowane również dla obszarów wykraczających poza linie rozgraniczające budowy.

\subsection{Realizacja - umowy kolizyjne}

Bardzo często rozpoczyna się inwestycję bez aktualnej inwentaryzacji kolizji oraz bez umów kolizyjnych nawet dla kolizji znanych . W tej sytuacji przedsiębiorstwo sieciowe nie ma podstaw prawnych do ustanawiania branżowego inspektora nadzoru. W większości przypadków jego obecność jest konieczna już na wczesnym etapie robót. Paradoksalnie godząc się na jego udział podmiot branżowy (gestor sieci) jakby legalizuje nieuregulowany stan prawny. Rozstrzygnięcia wymaga kwestia stron umowy kolizyjnej. Obecna praktyka zawierania umowy kolizyjnej pomiędzy inwestorem i właścicielem powinna być zastąpiona umową pomiędzy wykonawcą i właścicielem sieci. Wyeliminowałby to stały problem braku inspektorów nadzoru ze strony gestorów sieci.

\subsection{Realizacja - obszary zabytkowe}

Rada Ministrów w rozporządzeniu z listopada 2010 [4] podała wykaz przedsięwzięć mogących znacząco oddziaływać na środowisko. Konsekwencją tego rozporządzenia jest konieczność przeprowadzania oceny oddziaływania 
inwestycji na środowisko. Elementem tej oceny jest tzw. raport o oddziaływania przedsięwzięcia na środowisko. Decyzję o konieczności opracowania raportu podejmuje właściwy organ administracji po zapoznaniu się z kartą informacyjną przedsięwzięcia, która zawiera podstawowe dane o inwestycji, w tym również charakter oddziaływania na środowisko.

W odniesieniu do obszarów zabytkowych zapisy ustawy [1] ochronie zabytków i opiece nad zabytkami regulują warunki realizacji inwestycji na obszarach objętych ustawową ochroną. Należy podkreślić, że ochrona zabytków zgodnie z Art. 4 Ustawy [1] polega, na podejmowaniu przez organy administracji publicznej działań mających między innymi na celu: zapewnienie warunków prawnych, organizacyjnych i finansowych umożliwiających trwałe zachowanie zabytków oraz ich zagospodarowanie i utrzymanie co przekłada się na obligatoryjny warunek prowadzenia prac konserwatorskich, restauratorskich i oczywiście robót budowlanych za pozwoleniem właściwego konserwatora zabytków i pod jego nadzorem. Urząd Konserwatora Zabytków nadzoruje wszystkie etapy procesu inwestycyjnego. W przypadku obiektów lub obszarów zabytkowych wytyczne i zalecenia konserwatorskie odgrywają wiodącą rolę w całym procesie inwestycyjnym.

Należy podkreślić, że inwestycje liniowe na terenach zurbanizowanych bardzo często prowadzone są na obszarach nawarstwień antropogenicznych wraz ze znajdującymi się w nich zabytkami, dokumentującymi historię osadnictwa w danym rejonie. Odkrycie takich śladów wymaga każdorazowo zawiadomienia urzędu Konserwatora Zabytków w celu oceny ewentualnego stopnia zdegradowania i wydania decyzji o warunkach kontynuacji prac.

\subsection{Eksploatacja - zezwolenie na użytkowanie}

Dokument zamykający proces inwestycyjny to zezwolenie na użytkowanie. Uzyskanie zgody na użytkowanie wymaga złożenia we stosownym czasie (ustawowo 21 dni przed planowanym otwarciem) kompletnego ,kolaudatu" we właściwym urzędzie nadzoru budowlanego. Bardzo często dokumenty są niekompletne, co znacznie opóźnia i utrudnia rozpatrzenie wniosku i w efekcie wstrzymuje oddanie inwestycji. Najczęściej niekompletne są mapy geodezyjne, które stanowią obligatoryjny załącznik do wniosku. Problemy występują również w uzgodnieniu docelowej stałej organizacji ruchu lub dopuszczenie do eksploatacji tylko fragmentu inwestycji.

Nie bez znaczenia są także w związku z bardzo długim cyklem przygotowywania inwestycji zmiany w przepisach, a szczególnie zmiany w warunkach technicznych jakim powinny odpowiadać drogi publiczne i ich usytuowanie. Zmiany te bardzo często są powodem opóźnienia przekazania obiektu do użytkowania. Dodatkowym obowiązkiem dla inwestora może być wymaganie,

\footnotetext{
${ }^{7}$ Dokumentacja powykonawcza z naniesionymi zmianami dokonanymi w czasie realizacji inwestycji oraz pomiary geodezyjne
} 
w decyzji o ustaleniu środowiskowych uwarunkowań realizacji przedsięwzięcia, wykonania analizy porealizacyjnej. Należy podkreślić, że może to być kłopotliwe zadanie, często dodatkowo rozciągnięte w czasie np.: dla zabytkowych obszarów przyrodniczych. Konsekwencje niewykonania analizy mogą być dwojakiego rodzaju. Pierwszy rodzaj sankcji to grzywna ${ }^{8}$, natomiast drugi ma charakter administracyjny i może skutkować cofnięciem decyzji środowiskowej9.

\section{Podsumowanie}

Iinwestycje liniowe w miastach, w pasie drogowym i w pasie drogowym na obszarach chronionych ustawami o ochronie zabytków[1] i ochronie przyrody[3] wymagają szczególnej troski. Konieczne jest nie tylko spełnienie warunków formalno-prawnych i technicznych ale również konieczne jest uwzględnienie postulatów szeroko pojętej opinii społecznej.

Wrażliwość miejskiego systemu komunikacji i transport na działania inwestycyjno-remontowe w pasie drogowym wymaga współpracy z zarządcą drogi i porozumienia z mieszkańcami. W Warszawie bardzo pomocny okazał się wielostopniowy system koordynacji inwestycji miejskich.

Wdrożony w 2008 r. w Warszawie system e_inwetycje uzupełniono w ostatnich latach o bezpośrednie i pośrednie narzędzia do dialogu społecznego. Są to - ogólnie dostępna dla mieszkańców Warszawy platforma informacyjna www.infoulice.um.warszawa.pl oraz portal społecznościowy https://plpl.facebook.com/infoulice. Istotną rolę opiniotwórczą odgrywa również stała Komisja Dialogu Społecznego. W najbliższym czasie planuje się wdrożenie nowej wersji systemu e_inwestycje, który usprawni koordynację zadań inwestycyjnych $\mathrm{w}$ pasie drogowym oraz procedury zajęć pasa drogowego $\mathrm{w}$ warszawskiej aglomeracji miejskiej.

\section{Literatura}

[1] USTAWA z dnia 23 lipca 2003 r. o ochronie zabytków i opiece nad zabytkami. (Dz.U.2014.1446 - j.t.).

[2] USTAWA z dnia 7 lipca 1994 Prawo budowlane (Dz.U.2016.290 - j.t.).

[3] Ustawa z dnia 3 października 2008 r. o udostępnianiu informacji o środowisku i jego ochronie (Dz.U.2016.353 - j.t.).

[4] ROZPORZĄDZENIE RADY MINISTRÓW z dnia 9 listopada 2010 r. w sprawie przedsięwzięć mogących znacząco oddziaływać na środowisko (Dz. U. nr 213 poz. 1397), 2007.

\footnotetext{
${ }^{8} \mathrm{~W}$ trybie ustawy o postępowaniu egzekucyjnym $\mathrm{w}$ administracji

${ }^{9}$ Zg. z Art. 162 paragraf 2 kodeksu postępowania administracyjnego
} 


\section{THE NATURE OF CONSTRUCTING LINE INFRASTRUCTURE IN METROPOLITAN AREAS WITH HISTORIC AREAS}

\section{S u m m a r y}

This lecture will cover the issue of carrying out construction processes in cities. A number of challenges have to be overcome when constructing, reconstructing and renovating roads and line infrastructure in urban areas. These difficulties are not only of a technical nature, but also stem from broadlydefined social interactions. Investors tasked with carrying out construction projects within cities are required to seek out innovative technological solutions while, at the same time, trying to meet the often "lofty" expectations of the local community.

The lecture will discuss the typical threats a construction project may encounter on the example of a large metropolitan area, with a population of one million, in the stages of concept drawing, design, construction and operation, with particular emphasis placed on issues pertaining to the construction of line infrastructure in areas protected under the Historic Monuments Preservation Act of 23 July 2003. It should be noted that the preservation of historic monuments as outlined in Paragraph 4 of the abovementioned act involves the public administration bodies taking steps to provide legal, organizational and financial conditions enabling the permanent preservation of historic monuments, as well as their development and maintenance, which translates into the obligation to carry out restoration, renovation and construction work under the supervision of the Provincial Monument Conservator.

Line infrastructure construction interferes not only with historic monuments, but is also carried out in close proximity to archaeological sites, i.e. evidence of past human activity, located on the ground, below it or under water, providing evidence of cultural stratification and containing archaeological artefacts or traces thereof. The differing interests of all the parties taking part in such complicated construction projects in a complex legal environment may be reconciled by effectively coordinating investment processes and employing social dialogue mechanisms.

Keywords: construction, renovation, road infrastructure, urban areas, historic monument preservation, investment coordination, e-inwestycje system

Przestano do redakcji: 05.01.2017 r.

Przyjęto do druku: 31.03 .2017 r. 